\title{
Pengaruh Aktivitas Rantai Nilai Terhadap Kualitas dan Inovasi Produk
}

\author{
Gerai Alun Segara ${ }^{1}$, Titik Kusmantini ${ }^{2}$, Yekti Utami ${ }^{3}$ \\ Fakultas Ekonomi dan Bisnis, Universitas Pembangunan Nasional “Veteran” Yogyakarta \\ geraialun@gmail.com ${ }^{1}$
}

\begin{abstract}
Abstrak - Penelitian ini dilatarbelakangi oleh masalah yang timbul dari bahan baku utama pada UKM mebel yang tidak tentu sehingga pihak UKM mebel harus menyesuaikan aktivitas rantai nilai mereka untuk menjaga kualitas produk dan inovasi produk mereka. Dimensi yang dijadikan pada aktivitas rantai nilai disini adalah fokus pelanggan, manajemen penelitian \& pengembangan, manajemen proses, manajemen pemasok. Penelitian ini bertujuan untuk mengetahui pengaruh aktivitas rantai nilai terhadap kualitas produk dan inovasi produk. Penelitian menggunakan sampel penelitian UKM mebel yang ada di desa Tirtonirmolo, kecamatan Kasihan, kabupaten Bantul, Daerah Istimewa Yogyakarta dengan target sampel sebanyak 31 UKM mebel. Adapun teknik sampling dalam penelitian ini menggunakan teknik sensus dan ketika menguji hipotesis menggunakan teknik analisis regresi berganda. Hasil penelitian menunjukkan bahwa fokus pelanggan berpengaruh terhadap kualitas produk dan inovasi produk, manajemen penelitian \& pengembangan berpengaruh terhadap inovasi produk, manajemen proses berpengaruh terhadap kualitas produk, serta manajemen pemasok berpengaruh terhadap kualitas produk dan inovasi produk.
\end{abstract}

Kata Kunci- Aktivitas Rantai Nilai, Kualitas Produk, Inovasi Produk

\begin{abstract}
Abstact- This study was inspired by the scarcity of furniture raw materials so that the furniture SMEs should regulate their value chain activities to maintain their product quality and innovation. The observed value chain dimensions in this study were customer focus, research and development management, process management and supplier management. This study was intended to find out the effect of value chain activities on product quality and innovation. The samples were 31 furniture SMEs in Bantul, Special Territory of Yogyakarta. They were selected through census. The data were then analyzed through multiple linear regression. The result showed that the customer focus affected both product quality and innovation, research and development management affected product innovation, process management affected product quality and supplier management influenced both product quality and innovation.
\end{abstract}

Keywords: Value Chain Activities, Product Quality, Product Innovation.

\section{PENDAHULUAN}

Dewasa ini, dengan berkembang pesatnya pengetahuan dan teknologi dalam informasi serta komunikasi dapat menjadikan sarana yang lebih efesien dalam pendistribusian bagi produk baru Usaha Kecil dan Menengah (UKM). Di samping biaya yang relatif terjangkau, dalam penyebaran informasi dengan menggunakan teknologi yang modern akan lebih cepat dan luas (global). Maka dari itu, sebuah UKM harus dapat beradaptasi terhadap teknologi yang semakin modern dari zaman ke zaman. Agar UKM dapat bertahan dan bersaing untuk mendapatkan konsumen, tiap UKM harus berupaya mengendalikan kualitas produk dan mampu meningkatkan inovasi produk yang dapat mempengaruhi kesuksesan.

Pada sektor industri mebel yang dalam melaksanakan produksinya tidak lagi bebas menggunakan bahan baku. Sebagai pengolah kayu dan hasil hutan, para pengusaha industri mebel perlu mencermati dan memahami perubahan yang terjadi terkait dengan regulasi dibidang bahan baku dan hasil hutan. Peraturan tentang persyaratan pengadaan dan perdagangan kayu dan hasil hutan akan dapat mempengaruhi industri mebel secara langsung ataupun tidak langsung.

Dalam hal regulasi yang terjadi di Indonesia saat ini terdapat Sistem Verifikasi dan Legalitas Kayu (SVLK). SVLK merupakan sistem pelacakan yang disusun secara multistakeholder untuk memastikan legalitas sumber kayu yang beredar dan diperdagangkan di Indonesia. Sistem Verifikasi Legalitas Kayu (SVLK) dikembangkan untuk mendorong implementasi peraturan pemerintah yang berlaku terkait perdagangan dan peredaran hasil hutan yang legal di Indonesia (Daulay, 2015).

Dengan adanya SVLK, produk mebel di Indonesia merupakan salah satu komoditas yang memiliki potensi di pasar dalam negeri maupun luar negeri dan jika komoditas ini diolah secara professional maka akan memberikan nilai tambah yang lebih besar. Berdasarkan data kementrian perindustrian sepanjang bulan januari hingga november 2017, ekspor mebel nasional adalah senilai US $\$ 1,34$ miliar. Pada periode yang sama tahun 2018 industri mebel mencatatkan ekspor senilai US $\$ 1,48$ miliar (www.kemenperin.go.id). 
Dari semua produk yang disediakan oleh setiap industri mebel, kualitas mebel dan inovasi mebel adalah hal yang paling penting. Maka mengendalikan kualitas produk dan meningkatkan inovasi produk adalah kewajiban bagi seluruh industri mebel. Salah satu cara mengendalikan kualitas produk dan meningkatkan inovasi produk ialah dengan menggunakan aktivitas rantai nilai.

The resource-based view (RBV) memandang perusahaan sebagai kumpulan sumber daya dan kemampuan (Wernerfelt, 1984). Pendapat dari RBV yaitu bahwa perusahaan bersaing berdasarkan sumber daya dan kemampuan. Perbedaan sumber daya dan kemampuan perusahaan dengan perusahaan pesaing akan memberikan keuntungan kompetitif (Peteraf, 1993). Sumber daya perusahaan dapat dibagi menjadi tiga macam yaitu, berwujud, tidak berwujud dan sumber daya manusia (Grant, 2002). Kemampuan menunjukkan apa yang dapat dilakukan perusahaan dengan sumber dayanya (Amit and Schoemaker, 1993). Tingkat kemampuan perusahaan yang lebih tinggi dikenal dengan dinamika kemampuan / capability dynamics (Teece, Pisano, dan Shuen, 1997). Dinamika kemampuan merupakan kemampuan perusahaan untuk menciptakan, mempertahankan, atau mengubah kemampuan perusahaan lainnya (Winter 2003).

Selanjutnya, rantai nilai menguraikan perusahaan menjadi aktivitas-aktivitas yang relevan secara strategis untuk memahami perilaku biaya dan sumber diferensiasi yang sudah ada dan yang potensial (Porter, 1994). Rantai nilai menunjukan bagaimana sebuah produk bergerak dari tahap bahan baku ke pelanggan akhir (Hitt, Ireland, dan Hoskisson, 2001). Porter (1985) dalam Prajogo et al (2008) berpendapat bahwa UKM yang mengoptimalkan kegiatan rantai nilai mereka akan mempunyai kesempatan yang lebih baik untuk meningkatkan kemampuan dan keunggulan kompetitif yang berkelanjutan. Aktivitas rantai nilai berkaitan dengan pemasaran, desain, produksi, pengiriman, dan dukungan dari produk atau layanan. Aktivitas rantai nilai dapat membuat UKM mencapai keunggulan kompetitif yang berkelanjutan. Selanjutnya Prajogo et al (2008) berpendapat bahwa ada empat aktivitas dari rantai nilai, yaitu: Fokus pada Pelanggan (Costumor Focus), Manajemen Pengembangan \& Penelitian (R\&D Management), Manajemen Proses (Process Management), dan Manajemen Pemasok (Supplier Management).

Aktivitas rantai nilai yang pertama adalah fokus pada pelanggan. Fokus pada pelanggan termasuk salah satu misi UKM. UKM harus memiliki fokus pada pelanggan agar dapat memenuhi kebutuhan pelanggan. Menurut Vijande dan Gonzalez (2007) fokus yang kuat pada pelanggan dapat mengarah pada penekanan inovasi yang berasal dari keinginan untuk terus menerus beradaptasi dengan kebutuhan pelanggan.

Aktivitas rantai nilai yang kedua adalah manajemen pengembangan \& penelitian. Saat ini persaingan bisnis sangatlah ketat, umur produk dipasar tidak selamanya bisa bertahan karena banyak bermunculnya produk baru. Hal ini menuntut peran dari manajemen pengembangan \& penelitian pada suatu perusahaan sebagai salah satu cara agar perusahaan tetap melakukan inovasi. Menurut Som (2012) manajemen pengembangan \& penelitian merupakan sumber pengembangan aplikasi teknologi, disamping menciptakan sumber daya manusia yang terampil dan berkualitas. Sedangkan menurut Kotler (2012) mengembangkan konsep produk menjadi produk fisik untuk meyakinkan bahwa gagasan produk dapat diubah menjadi produk yang dapat diwujudkan. Aktivitas rantai nilai yang ketiga adalah manajemen proses. Dewasa ini, mengutamakan kualitas sangatlah penting dikarenakan perusahaan tidak akan dapat bersaing jika kualitas produknya buruk. Maka dari itu manajemen proses sebagai salah satu cara untuk mengawasi kualitas produk perusahaan. Griffin dan Ebert (2002) berpendapat bahwa manajemen merupakan proses perencanaan, pengorganisasian, pengarahan, dan pengawasan sumber daya keuangan, fisik, manusia, serta infomasi suatu perusahaan untuk mencapai tujuannya.

Aktivitas rantai nilai yang terakhir adalah manajemen pemasok. Peran pemasok dalam mencapai kualitas produk yang unggul telah diakui dalam arena rantai pasokan. Menurut De Jong dan Vermuelen (2006) menggunakan jaringan eksternal seperti pemasok merupakan praktek penting dalam inovasi. Prajogo et al (2008) menemukan bahwa aktivitas rantai nilai mempunyai hubungan dengan kualitas produk dan inovasi produk. Penelitian terdahulu dilakukan pada 194 manajer dari UKM yang berada di Australia, implikasi dari aktivitas rantai nilai cenderung berhubungan dengan spesifikasi kinerja. Hal ini menunjukan bahwa manajer dapat memperoleh hasil dengan menargetkan elemen tertentu dari aktivitas rantai nilai sebagai sarana untuk mencapai hasil yang kompetitif.

Kualitas produk sangat menentukan akan keberhasilan persaingan perdagangan. Bagi perusahaan sangat prnting untuk menjaga konsistensi kualitas produk yang dihasilkan sesuai dengan tuntutan pasar. Kualitas produk adalah kemampuan suatu 
barang untuk memberikan hasil yang sesuai atau melebihi dari apa yang diinginkan pelanggan (Kotler, 2012).

Inovasi merupakan upaya untuk mengeksploitasi perubahan menjadi suatu kesempatan bagi UKM industri mebel, atau bagaimana mengolah ide baru tersebut untuk sukses. Dengan melakukan proses inovasi, UKM industri mebel berharap dapat menciptakan produk baru atau berbeda dari sebelumnya atau membuat produk dari produk sebelumnya yang merupakan penyempurnaan dari produk yang sudah ada. Dwyer (1987) dalam Prajogo et al (2008) menyatakan munculnya inovasi produk pada dasarnya adalah untuk memenuhi permintaan pasar sehingga inovasi produk merupakan salah satu langkah yang dapat digunakan sebagai keunggulan kompetitif bagi UKM. Keberhasilan dan kemampuan bersaing perusahaan akan bergantung pada kemampuannya untuk melakukan inovasi (Pistorius, 2001, dalam Siringoringo et al, 2012).

Pada UKM mebel di desa Tirtonirmolo, Kecamatan Kasihan, Kabupaten Bantul, Daerah Istimewa Yogyakarta yang membuat peralatan rumah tangga seperti lemari, kursi, meja dan lainnya. Inovasi yang dapat dilakukan oleh industri mebel saat ini adalah pengembangan produk dan pengolahan kayu agar menjadi produk-produk yang berkualitas tinggi. Meningkatnya persaingan dalam dunia bisnis khususnya bisnis UKM Industri Meubel tentunya akan menimbulkan ancaman dan peluang. Dalam dunia persaingan usaha dikenal dengan dinamika persaingan yang berarti perubahan-perubahan yang terjadi terhadap persaingan yang terjadi pada perusahaan dalam memperebutkan pelanggan pada periodeperiode tertentu. Maka dari itu setiap perusahaan perlu memperhatikan dinamika yang terjadi agar mereka bisa mengikuti persaingan agar tidak mengalami kekalahan dalam kompetisi di pasar.

Perkembangan UKM di Indonesia saat ini tidak terlepas dari berbagai macam masalah yang ada. Salah satu permasalahan yang dihadapi oleh UKM di Indonesia, khususnya Industri Mebel di desa Tirtonirmolo, Kecamatan Kasihan, Kabupaten Bantul, Daerah Istimewa Yogyakarta adalah keterbatasan dalam mendapatkan bahan baku dengan kualitas yang baik dan harga yang terjangkau, serta keterbatasan beradaptasi dengan teknologi yang lebih modern untuk memajukan UKM industri mebel serta mendistribusikan hasil produksinya dengan lebih efektif dan efisien. Dalam memasuki era Masyarakat Ekonomi Asean (MEA), UKM Mebel khususnya Industri Mebel di desa Tirtonirmolo, Kecamatan
Kasihan, Kabupaten Bantul, Daerah Istimewa Yogyakarta bukan hanya dituntut untuk memproduksi mebel dengan harga yang bersaing, namun juga dituntut untuk mampu menyesuaikan desain mebel sesuai dengan permintaan pasar maupun permintaan perorangan. Pada pengembangan UKM industri mebel di desa Tirtonirmolo, Kecamatan Kasihan, Kabupaten Bantul, Daerah Istimewa Yogyakarta saat ini para pelaku usaha mebel tentunya harus memiliki inovasi pada produknya.

Penelitian ini akan ditujukan pada UKM Industri Mebel, desa Tirtonirmolo, Kecamatan Kaishan, Kabupaten Bantul, Daerah Istimewa Yogyakarta. Lokasi tersebut dipilih karena di desa Tirtonirmolo, Kecamatan Kasihan, Kabupaten Bantul, Daerah Istimewa Yogyakarta cukup banyak memiliki pengrajin yang berbasis UKM di Industri Mebel. Selain itu, terdapat banyak potensi khususnya dalam produk mebel yang dapat dikembangkan lagi, baik dari segi ketersediaan bahan baku produk, kualitas, inovasi, pesaing maupun dari segi pengelolaan UKM. Kemudian penelitian ini selanjutnya ingin mengetahui dan menganalisis pengaruh aktivitas nilai rantai terhadap kualitas dan inovasi produk.

Aktivitas rantai nilai

\section{KAJIAN PUSTAKA}

Fokus utama dalam rantai nilai terletak pada keuntungan yang ditambahkan kepada konsumen, proses saling menguntungkan yang menghasilkan nilai, dan permintaan yang dihasilkan serta aliran dana yang dibuat (Feller, Shunk, Callarman, 2006).Prajogo et al (2008) berpendapat bahwa rantai nilai memiliki empat aktivitas yang mempengaruhi kualitas produk dan inovasi produk, yaitu:

Fokus Pelanggan

Fokus pada pelanggan menurut international standard organization (2000) ialah manajemen harus menjamin persyaratan/keinginan pelanggan yang ditetapkan dan dipenuhinya tujuan meningkatkan kepuaasan pelanggan. Sedangkan menurut Munizu (2010) customer focus merupakan strategi fokus terhadap pelanggan yang menjadi salah satu faktor mikro dalam suatu perusahaan yang mempengaruhi perubahan dan pengembangan kinerja suatu organisasi dan juga salah satu perubahan yang secara signifikan mempengaruhi kinerja karyawan dan kinerja bisnis.

Manajemen Pengembangan \& penelitian

Harryson (1997) berpendapat bahwa menilai inovasi kinerja UKM dengan mengukur tingkat kegiatan R\&D nya. Menurut Mikkola (2001) R\&D memiliki dua peranan utama dalam mencapai inovasi 
yang unggul, yaitu, yang pertama adalah dalam produk baru dan proses pembangunan. Kemudian yang kedua adalah efektivitas R\&D manajemen dalam pembangunan ini tergantung pada kemampuannya untuk bekerja sama dengan pemasaran dan manufaktur. Goffin dan New (2001) berpendapat bahwa keberhasilan teknologi UKM secara sadar berinvestasi dalam proses manajemen inti UKM, terutama pada pengembangan produk, strategi produk, dan integrasi rantai psokan akan memberikan kompetensi yang memberikan keunggulan kompetitif. Inilah sebabnya mengapa teknologi pada UKM telah menjadi pelopor dalam kemajuan lintas fungsional manajemen proses.

Manajemen Proses

Griffin dan Ebert (2002) menjelaskan bahwa manajemen merupakan proses perencanaan, pengorganisasian, pengarahan, dan pengawasan sumber daya keuangan, fisik, manusia, dan informasi suatu perusahaan untuk mecapai tujuannya. Terry (2005) memberi pengertian manajemen yaitu suatu proses atau kerangka kerja, yang melibatkan bimbingan atau pengarahan suatu kelompok orangorang kearah tujuan-tujuan organisasional atau maksud yang nyata. Hal tersebut meliputi pengetahuan tentang apa yang harus dilakukan, menetapkan cara bagaimana melakukannya, memahami bagaimana mereka harus melakukannya dan mengukur efektivitas dari usaha-usaha yang telah dilakukan.

Manajemen Pemasok

Peran pemasok dalam mencapai kualitas yang unggul telah diakui dalam lingkup rantai pasokan. Pemasok sangat berhubungan dengan UKM dikarenakan UKM melakukan kegiatan akhir pada rantai pasokan hingga sampai ke tangan konsumen. McGinnis dan Vallopra (1999) menunjukkan bahwa nilai keterlibatan pemasok sangat bijaksana dalam menentukan kesuksesan produk melalui penerapan mengidentifikasi pemasok, pemilihan pemantauan, dan pengendalian.

Kualitas Produk

Kotler (2012) menyatakan kualitas produk adalah kemampuan suatu barang untuk memberikan hasil/kinerja yang sesuai atau melebihi dari apa yang diinginkan pelanggan. Menurut Kotler (2012), produk adalah elemen kunci dalam keseluruhan penawaran pasar. Selain itu produk dapat pula didefinisikan sebagai persepsi konsumen yang dijabarkan oleh produsen melalui hasil produksinya (Tjiptono, 2008). Inovasi Produk

Tjiptono (2008) menyatakan bahwa inovasi merupakan penerapan secara praktis sebuah gagasan ke dalam suatu produk atau proses baru. Inovasi adalah kondisi pada barang dan jasa bahkan gagasan yang dianggap sebagai sesuatu yang baru (Kotler, 2012). Sedangkan menurut Suendro (2010) bahwa inovasi produk yang semakin tinggi akan mempengaruhi kinerja pemasaran dan selanjutnya meningkatkan keunggulan bersaing berkelanjutan.

Telaah Penelitian Sebelumnya

Dalam penelitian ini penulis memaparkan penilitian terdahulu yang relevan dengan permasalahan yang akan diteliti tentang pengaruh aktivitas rantai nilai terhadap kualitas dan inovasi produk pada UKM Mebel di Desa Tirtonirmolo, Daerah Istimewa Yogyakarta.

Konsep yang dipakai oleh penulis adalah penelitian Prajogo et al (2008) yang meneliti tentang hubungan antara aktivitas rantai nilai dengan kualitas dan inovasi produk. Serta Prajogo et al (2008) memaparkan analisis pengaruh fokus pelanggan dengan kualitas produk dan inovasi produk, manajemen penelitian \& pengembangan berpengaruh terhadap inovasi produk, manajemen proses berpengaruh terhadap kualitas produk, manajemen pemasok berpengaruh terhadap kualitas produk dan inovasi produk.

Hasilnya menunjukkan bahwa aktivitas rantai nilai memengaruhi kualitas produk dan inovasi produk, baik itu dari dimensi aktivitas rantai nilai terhadap kualitas produk dan inovasi produk. Yang mana hal ini dikatakan dapat meningkatkan kemampuan kompetitif di perusahaan. Prajogo et al (2008) memaparkan tentang fokus pelanggan, manajemen penelitian \& pengembangan, manajemen proses dan manajemen pemasok adalah faktor yang cukup penting dalam aktivitas rantai nilai. Dikatakan bahwa aktivitas rantai nilai dapat berperan terhadap kualitas produk dan inovasi produk dengan hasil memberi manfaat seperti persediaan yang efisien, beban yang berkurang, meningkatkan pemanfaatan sumber daya, meningkatkan produktivitas, efisiensi pengorganisasian, meningkatkan pelayanan, respon cepat, efisiensi siklus waktu, jaringan yang berkembang.

Pengaruh fokus pelanggan terhadap kualitas produk dan inovasi produk

Pemasaran melakukan peran penting dalam rantai nilai, karena hal itu mempengaruhi hubungan antara suatu perusahaan dan pelanggan di prapengembangan dan tahap pasca-pengiriman. Pada tahap pra-pengembangan, fokus pelanggan adalah yang terpenting dalam memahami kebutuhan pelanggan sebelum produk dapat dirancang dan 
dikembangkan. Pada tahap pasca-pengiriman, membahas isu-isu layanan pelanggan dan kepuasan. Para pendukung TQM (Total Quality Management) mempertimbangkan fokus pelanggan sebagai titik awal untuk filosofi kualitas (Deming, 1986).

Dalam lingkungan manufaktur yang sebenarnya, perusahaan harus mengambil inisiatif sukses untuk menjadi kompetitif. persaingan global, teknologi baru dan meningkatnya permintaan untuk produk-produk unggulan di periode yang lebih pendek, memotivasi organisasi untuk menerima dan mengadopsi baru dan inisiatif pandangan untuk inovasi produk (Noori \& Ebrahimi, 2005).

Cho dan Pucik (2005) menunjukkan bahwa kemampuan perusahaan untuk menyeimbangkan antara efek inovasi dan kualitas pada pertumbuhan dan profitabilitas merupakan faktor keberhasilan organisasi yang penting dan efektif.

H1: fokus pelanggan berpengaruh positif terhadap kualitas produk

$\mathrm{H} 2$ : fokus pelanggan berpengaruh positif terhadap inovasi produk

Pengaruh manajemen penelitian \& pengembangan terhadap inovasi produk

Menurut Sugiyono (2011) penelitian dan pengembangan adalah metode penelitian yang digunakan untuk menghasilkan produk tertentu, dan menguji keefektifan produk tersebut. Pentingnya R \& D tidak hanya telah dibuktikan oleh perusahaanperusahaan inovatif internasional seperti Sony dan Canon, tapi juga studi empiris telah mendukung hubungan antara kegiatan inovasi dan R \& D dengan investasi dalam organisasi (Hall dan Bagchi-Sen, 2002).

Pada tingkat strategis, manajemen $\mathrm{R}$ \& $\mathrm{D}$ dapat digunakan dalam berbagai kasus, termasuk nilai tambah produksi, bersama-sama dengan faktor potensi bisnis yang ada terhadap pembangunan besar produk baru menggantikan yang usang (Lowe, 1995).

H3: manajemen pengembangan \& penelitian berpengaruh positif terhadap inovasi produk.

Pengaruh manajemen proses terhadap Kualitas Produk

Prinsip-prinsip TQM menekankan kebutuhan untuk mengidentifikasi cacat selama proses kerja, melacak mereka ke sumber mereka, menentukan penyebabnya, dan untuk mengambil tindakan pencegahan (Hackman dan Wageman, 1995). Deming (1986) menekankan pentingnya pengendalian proses melalui pengendalian proses statistik (SPC) teknik sebagai alat utama peningkatan kualitas produk. Menurut Shingo (1986) terdapat pergeseran dari penekanan korektif untuk praktek lebih preventif, dan ini termasuk penggunaan mekanisme dan alat gagalaman.

H4: manajemen proses berpengaruh positif terhadap kualitas produk.

Pengaruh manajemen pemasok terhadap kualitas produk dan inovasi produk

Beberapa peneliti percaya bahwa dalam lingkungan yang kompetitif saat ini, perusahaanperusahaan bersaing atas akses ke rantai pasokan (Fynes et al, 2005). Untuk mengakses rantai pasokan, perusahaan harus membuat strategi yang baik. Kualitas dan keberhasilan rantai pasokan tergantung pada kualitas informasi yang tersedia (Cruise et al, 1998) dan pada jaringan informasi dan konvergensi Technologic (Sahay \& Moham, 2003). Perlu dicatat bahwa rantai pasokan dikelilingi oleh pasukan yang kompleks dan tidak terkendali (Peck, 2005).

Selanjutnya, Juran (1989) mengusulkan penggunaan sistem peringkat vendor sebagai sarana sistematis untuk memilih pemasok. Dengan menilai kemampuan pemasok sebelum keputusan untuk membeli bahan atau produk.

H5: manajemen pemasok berpengaruh positif terhadap kualitas produk.

H6: manajemen pemasok berpengaruh positif terhadap inovasi produk.

Berdasarkan hipotesis maka kerangka penelitian untuk menelusuri hubungan berbagai pengaruh variabel diilustrasikan dalam gambar sebagai berikut:

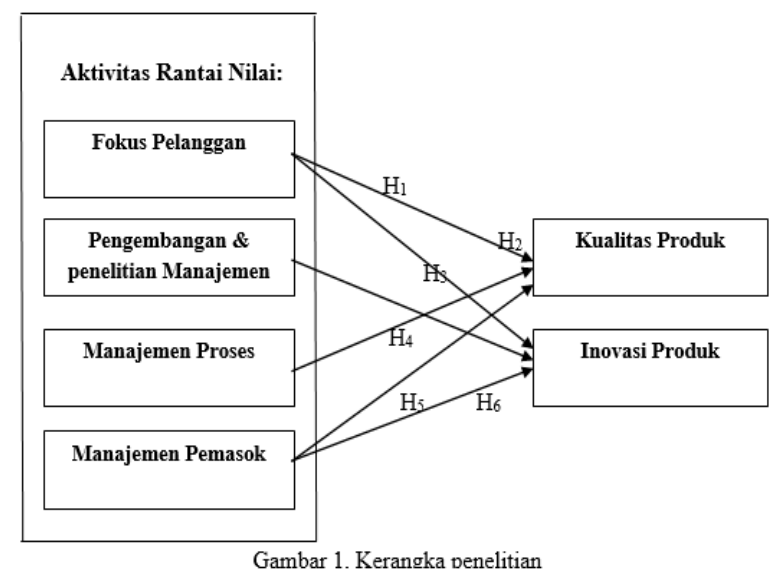

III. METODE PENELITIAN

Metode yang digunakan dalam penelitian ini adalah metode survei. Penelitian survei digunakan untuk mendapatkan data dari tempat tertentu yang alamiah, tetapi peneliti melakukan perlakuan dalam pengumpulan data misalnya dengan mengedarkan kuesioner, test, wawancara terstruktur (Sugiyono, 
2011). Pada penelitian ini peneliti mencari pengaruh aktivitas rantai nilai terhadap kualitas dan inovasi produk.

Menurut Sugiyono (2011), populasi dapat didefinisikan sebagai wilayah generalisasi yang terdiri dari obyek atau subyek yang mempunyai kuantitas dan karakteristik tertentu yang ditetapkan oleh peneliti untuk dipelajari dan kemudian ditarik kesimpulannya. Populasi dalam penelitian ini adalah UKM Industri Mebel yang berada di desa Tirtonirmolo, Kecamatan Kasihan, Kabupaten Bantul, Daerah Istimewa Yogyakarta yang berjumlah 31 UKM (https://iogjaprov.go.id)

Sampel sebagai sebagaian dari jumlah dan karakteristik yang diambil dari populasi penelitian yang sudah ditentukan. Keterbatasan wilayah membuat peneliti memutuskan untuk mengambil beberapa sampel dari populasi penelitian ini dengan mengacu pada kriteria jumlah sampel yang bisa digunakan. Ukuran sampel yang layak menurut Sugiyono (2011) adalah antara 30 sampai dengan 500.

Teknik pengambilan sampel dalam penelitian ini menggunakan sampling jenuh (sensus) yaitu teknik pengambilan sampel bila semua anggota populasi digunakan sebagai sampel (Sugiyono, 2011). Dari pengertian diatas diperoleh sampel sebanyak 31 UKM Mebel yang berada di desa Tirtonirmolo, Kecamatan Kasihan, Kabupaten Bantul, Daerah Istimewa Yogyakarta. Hal ini dikarenakan seluruh anggota UKM Mebel di Kecamatan Kasihan menerapkan aktivitas rantai nilai.

Dalam penelitian ini, jenis data yang akan digunakan adalah data primer. Menurut Sugiyono (2011) data primer adalah data yang diperoleh secara langsung dari sumber asli atau tempat dimana penulis mengadakan penelitian untuk diamati dan dicatat. Dalam hal ini data primer berupa hasil kuesioner yang diisi oleh responden yaitu pemilik atau pengelola UKM Mebel di desa Tirtonirmolo, Kecamatan Kasihan, Kabupaten Bantul, Daerah Istimewa Yogyakarta tentang aktivitas rantai nilai usaha mereka.

Teknik pengumpulan data dalam penelitian ini yaitu dengan menyebarkan daftar pertanyaan/kuesioner yang disampaikan secara langsung kepada masing-masing UKM Industri Mebel yang ada di desa Tirtonirmolo, Kecamatan Kasihan, Kabupaten Bantul, Daerah Istimewa Yogyakarta agar peneliti mendapat respon yang tinggi dari responden.

Menurut Sutoyo (2009) Angket atau kuesioner merupakan sejumlah daftar pertanyaan atau pertanyaan tertulis tentang data faktual atau opini yang berkaitan dengan responden yang dianggap fakta atau kebenenaran yang diketahui dan perlu dijawab oleh responden.

Definisi operasional variabel merupakan variabel dependen yang dipengaruhi atau yang menjadi akibat karena adanya variabel bebas (Sugiyono, 2011). Variabel-variabel yang digunakan dalam penelitian ini:

\section{Rantai Nilai}

Rantai nilai merupakan serangkaian aktivitas yang relevan dalam proses pengadaan, penyimpanan, penggunaan, transformasi, dan disposisi sumber daya, mulai dari rantai nilai pemasok sampai rantai nilai pembeli, mulai dari aktivitas pengamanan sumbersumber pasokan sampai aktivitas pelayanan purna jual (Tjiptono, 2008). Adapun aktivitas-aktivitas rantai nilai meliputi beberapa dimensi yakni fokus pelanggan, manajemen penelitian \& pengembangan, manajemen proses, dan manajemen pemasok (Prajogo, 2008).

\section{Fokus Pelanggan}

Fokus pelanggan adalah bagaimana cara perusahaan mengetahui apa yang diinginkan pelanggan/konsumen dan memenuhinya dengan meletakkan kepuasan serta nilai-nilai pelanggan sebagai hal yang utama dan transaksi sebagai dasar analisis (Prajogo, 2008). Indikator fokus pelanggan meliputi:

1) Kebutuhan dan harapan pelanggan

2) Pemahaman karyawan tentang kebutuhan pelanggan

3) Melibatkan pelanggan dalam proses desain produk

4) Menjaga hubungan baik dengan pelanggan

5) Proses yang efektif untuk menyelesaikan keluhan pelanggan

6) Mengukur kepuasan pelanggan

\section{Manajemen Penelitian \& pengembangan}

Manajemen pengembangan \& penelitian merupakan proses mengelola inovasi di suatu perusahaan agar dapat berdaya guna bagi pencipta keunggulan bersaing yang berkelanjutan bagi perusahaan. Indikator manajemen penelitian \& pengembangan dalam penelitian ini diambil dari penelitian Prajogo (2008), yang meliputi:

1) Proses komunikasi yang baik antar departemen lain

2) Mengejar penelitian yang inovatif

3) Proyek berisiko tinggi dengan pengembalian yang tinggi

4) Manajemen penelitian \& pengembangan penting dalam penelitian strategis

\section{Manajemen Proses}


Manajemen proses meyangkut tentang bagaimana cara mendesain dan mengendalikan hasil ketika diproduksi (Deming,1986). Indikator manajemen proses dalam penelitian ini diambil dari penelitian Prajogo (2008), yang meliputi:

1) Menerapkan konsep pelanggan internal

2) Merancang proses untuk menjadi preventif

3) Intruksi proses yang jelas, standarisasi dan terdokumentasi yang mudah dipahami karyawan

4) Menggunakan teknik statistic

\section{Manajemen Pemasok}

Manajemen pemasok menciptakan hubungan yang lebih dekat dan lebih kolaboratif dengan pihak pemasok untuk mengurangi resiko. Indikator manajemen pemasok dalam penelitian ini diambil dari penelitian Prajogo (2008), yang meliputi:

1) Usaha untuk menjalin hubungan jangka panjang dengan pemasok

2) Menggunakan sistem penelitian untuk memilih pemasok

3) Mengandalkan sejumlah pemasok yang handal

4) Pemasok terlibat dalam proses pengembangan produk

\section{Kualitas Produk}

Kualitas produk dapat diartikan segala sesuatu yang dapat ditawarkan kepasar untuk mendapatkan perhatian, dibeli, digunakan, atau dikonsumsi yang dapat memuaskan keinginan atau kebutuhan. Indikator kualitas produk dalam penelitian ini diambil dari penelitian Prajogo (2008), yang meliputi:

1) Kinerja

2) Kesesuaian dengan spesifikasi

3) Kehandalan

4) Daya tahan

\section{Inovasi Produk}

Pengertian inovasi adalah suatu ide, gagasan, praktek atau obyek yang disadari dan diterima sebagai suatu hal baru oleh seseorang atau kelompok untuk diadopsi. Indikator inovasi produk dalam penelitian ini diambil dari penelitian Prajogo (2008), yang meliputi:

1) Perluasan lini produk/tingkat kebaruan

2) Penggunaan inovasi teknologi terbaru

3) Kecepatan pengembangan produk baru

4) Jumlah produk baru

5) Produk muncul pertama kali di pasar

\section{HASIL DAN PEMBAHASAN}

Analisis kuantitatif yang digunakan dalam penelitian ini yakni analisis regresi berganda dengan tujuan untuk mengetahui pengaruh variabel-variabel independen terhadap variabel-variabel dependen.

\section{Analisis regresi berganda}

Hasil analisis regresi berganda ditunjukan untuk menguji hipotesis ada atau tidaknya pengaruh dimensi aktivitas rantai nilai (fokus pelanggan, manajemen pengembangan \& penelitian, manajemen proses, manajemen pemasok) terhadap kualitas produk dan inovasi produk. Pengujian hipotesis dengan menggunakan tingkat signifikan level 0,05 $(\alpha=5 \%)$. Jika nilai signifikansi $>0,05$ maka hipotesis ditolak/tidak signifikan, dan apabila nilai signifikansi $\leq 0,05$ maka hipotesis diterima/signifikan.

Pengaruh fokus pelanggan, manajemen proses, dan manajemen pemasok terhadap kualitas produk

Berdasarkan hasil analisis regresi berganda pada tabel 4.4 diperoleh persamaan regresi sebagai berikut: $\mathrm{Y} 1=-0,258+0,388 \mathrm{X} 1+0,370 \mathrm{X} 3+0,351 \mathrm{X} 4$

Didalam persamaan tersebut diperoleh nilai konstanta sebesar $-0,258$ yang berarti bahwa kualitas produk (Y1) menunjukan nilai konstanta -0,258 tanpa dipengaruhi oleh variabel fokus pelanggan (X1), manajemen proses (X3), manajemen pemasok (X4). Pada koefesien regresi fokus pelanggan diperoleh (X1) $=0,388$ yang berarti bahwa variabel fokus pelanggan mempunyai koefesien regresi yang positif terhadap kualitas produk dengan koefesien regresi sebesar 0,388 . Jika fokus pelanggan semakin baik, maka variabel kualitas produk (Y1) akan semakin baik dan sebaliknya dengan asumsi variabel lainnya konstan.

Pada persamaan tersebut juga diperoleh koefesien regresi manajemen proses $(\mathrm{X} 3)=0,370$ yang menunjukan bawa variabel manajemen proses mempunyai koefesien regresi yang positif terhadap kualitas produk dengan koefesien regresi sebesar 0,370. Jika manajemen proses semakin baik, maka variabel kualitas produk (Y1) akan semakin baik dan sebaliknya dengan asumsi variabel lainnya konstan. Kemudian juga diperoleh koefesien regresi manajemen pemasok $(\mathrm{X} 4)=0,351$. Pada variabel manajemen pemasok mempunyai koefesien regresi yang positif terhadap kualitas produk dengan koefesien regresi sebesar 0,351. Jika manajemen pemasok semakin baik, maka variabel kualitas produk (Y1) akan semakin baik dan sebaliknya dengan asumsi variabel lainnya konstan.

\section{Uji Signifikansi Model dan Koefesien Determinan $\mathbf{R}^{2}$ (Uji F)}

Berdasarkan hasil analisis regresi yang telah dirangkum pada tabel 4.4 diketahui nilai signifikansi $\mathrm{F}$ $=0.000 \leq 0.05$ (level significant), hal ini menunjukan bahwa variabel fokus pelanggan (X1), manajemen 
proses (X3), dan manajemen pemasok (X4) berpengaruh secara bersama-sama terhadap variabel kualitas produk (Y1) pada UKM mebel di Desa Tirtonirmolo, Kecamatan Kasihan, Kabupaten Bantul, DIY.

Adjusted $\mathrm{R}^{2}$ diperoleh sebesar 0.774 atau $77,4 \%$ yang artinya variabel fokus pelanggan (X1), manajemen proses (X3), dan manajemen pemasok (X4) memberikan kontribusi secara bersama-sama terhadap variabel dependen yaitu kualitas produk (Y1) $77,4 \%$ sedangkan sisanya sebesar $22,6 \%$ dijelaskan oleh variabel lainnya di luar model.

\section{Uji Koefisien Regresi dengan Uji t}

Uji ini dilakukan untuk melihat pengaruh variabel fokus pelanggan (X1), manajemen proses (X3), manajemen pemasok (X4) secara parsial terhadap variabel kualitas produk (Y1) pada UKM Mebel di Desa Tirtonirmolo, Kecamatan Kasihan, Kabupaten Bantul, DIY. Koefesien regresi dengan uji $\mathrm{t}$ dari hasil analisis regresi yang ditunjukan pada tabel 4.4 dapat dijelaskan sebagai berikut:

Variabel fokus pelanggan (X1) memiliki nilai signifikansi t sebesar $0.000 \leq 0.050$, maka variabel fokus pelanggan (X1) berpengaruh positif terhadap variabel kualitas produk (Y1), maka hipotesis 1 dapat diterima.

Variabel manajemen proses (X3) memiliki nilai signifikansi t sebesar $0.003 \leq 0.050$, maka variabel manajemen proses (X3) berpengaruh positif terhadap variabel kualitas produk (Y1), maka hipotesis 4 dapat diterima.

Variabel manajemen pemasok (X4) memiliki nilai signifikansi t sebesar $0.000 \leq 0.050$, maka variabel manajemen pemasok (X4) berpengaruh positif terhadap variabel kualitas produk (Y1), maka hipotesis 5 dapat diterima.

\section{Tabel 4.1 Hasil analisis regresi berganda tahap 1}

\begin{tabular}{lcccc}
\hline \multicolumn{1}{c}{ Variabel } & $\begin{array}{c}\text { Koef. } \\
\text { regresi }\end{array}$ & t hitung & Sig.t & Sig. 5\% \\
\hline Konstanta &,- 258 & & & \\
\hline $\begin{array}{l}\text { Fokus } \\
\text { Pelanggan }\end{array}$ &, 388 & 4,263 &, 000 & Signifikan \\
\hline $\begin{array}{l}\text { Manajemen } \\
\text { Proses }\end{array}$ &, 370 & 3,219 &, 003 & Signifikan \\
\hline $\begin{array}{l}\text { Manajemen } \\
\text { Pemasok }\end{array}$ &, 351 & 4,010 &, 000 & Signifikan \\
\hline $\begin{array}{l}\text { Variabel dependen : Kualitas Produk } \\
\text { Adjusted R Square }=0.774 \\
\text { F hitung = 35.234 }\end{array}$ & & & \\
\hline Sig.F =0.000 & & & \\
\hline
\end{tabular}

Sumber: Data primer yang diolah, 2019.

\section{Pengaruh fokus pelanggan, manajemen pengembangan \& penelitian, dan manajemen pemasok terhadap inovasi produk}

Berdasarkan hasil analisis regresi berganda pada tabel 4.5 diperoleh persamaan regresi sebagai berikut: $\mathrm{Y}=-0,242+0,353 \mathrm{X} 1+0,321 \mathrm{X} 2+0,374 \mathrm{X} 4$

Didalam persamaan tersebut diperoleh nilai konstanta sebesar -0,242 yang berarti bahwa inovasi produk (Y2) menunjukan nilai konstanta -0,242 tanpa dipengaruhi oleh variabel fokus pelanggan (X1), manajemen pengembangan \& penelitian (X2), manajemen pemasok (X4). Pada koefesien regresi fokus pelanggan diperoleh $(\mathrm{X} 1)=0,353$ yang berarti bahwa variabel fokus pelanggan mempunyai koefesien regresi yang positif terhadap inovasi produk dengan koefesien regresi sebesar 0,353 . Jika fokus pelanggan semakin baik, maka variabel inovasi produk (Y2) akan semakin baik dan sebaliknya dengan asumsi variabel lainnya konstan.

Pada persamaan tersebut juga diperoleh koefesien regresi manajemen pengembangan \& penelitian $(\mathrm{X} 2)=0,321$ yang menunjukan bawa variabel manajemen pengembangan \& penelitian mempunyai koefesien regresi yang positif terhadap inovasi produk dengan koefesien regresi sebesar 0,321. Jika manajemen pengembangan \& penelitian semakin baik, maka variabel inovasi produk (Y2) akan semakin baik dan sebaliknya dengan asumsi variabel lainnya konstan. Kemudian juga diperoleh koefesien regresi manajemen pemasok $(\mathrm{X} 4)=0,374$. Pada variabel manajemen pemasok mempunyai koefesien regresi yang positif terhadap inovasi produk dengan koefesien regresi sebesar 0,374. Jika manajemen pemasok semakin baik, maka variabel inovasi produk (Y2) akan semakin baik dan sebaliknya dengan asumsi variabel lainnya konstan.

\section{Uji Signifikansi Model dan Koefesien Determinan $\mathbf{R}^{2}$ (Uji F)}

Berdasarkan hasil analisis regresi yang telah dirangkum pada tabel 4.5 diketahui nilai signifikansi $\mathrm{F}$ $=0.000 \leq 0.05$ (level significant), hal ini menunjukan bahwa variabel fokus pelanggan (X1), manajemen pengembangan \& penelitian (X2), dan manajemen pemasok (X4) berpengaruh secara bersama-sama terhadap variabel inovasi produk (Y2) pada UKM mebel di Desa Tirtonirmolo, Kecamatan Kasihan, Kabupaten Bantul, DIY.

Adjusted $\mathrm{R}^{2}$ diperoleh sebesar 0.637 atau $63,7 \%$ yang artinya variabel fokus pelanggan (X1), manajemen pengembangan \& penelitian (X2), dan manajemen pemasok (X4) memberikan kontribusi secara bersama-sama terhadap variabel dependen yaitu 
inovasi produk (Y2) 63,7\% sedangkan sisanya sebesar $36,3 \%$ dijelaskan oleh variabel lainnya di luar model.

\section{Uji Koefisien Regresi dengan Uji t}

Uji ini dilakukan untuk melihat pengaruh variabel fokus pelanggan (X1), manajemen pengembangan \& penelitian (X2), manajemen pemasok (X4) secara parsial terhadap variabel inovasi produk (Y2) pada UKM Mebel di Desa Tirtonirmolo, Kecamatan Kasihan, Kabupaten Bantul, DIY. Koefesien regresi dengan uji t dari hasil analisis regresi yang ditunjukan pada tabel 4.5 dapat dijelaskan sebagai berikut:

Variabel fokus pelanggan (X1) memiliki nilai signifikansi t sebesar $0.009 \leq 0.050$, maka variabel fokus pelanggan (X1) berpengaruh positif terhadap variabel inovasi produk (Y2), maka hipotesis 2 dapat

\section{diterima.}

Variabel manajemen pengembangan \& penelitian (X2) memiliki nilai signifikansi t sebesar $0.027 \leq 0.050$, maka variabel manajemen pengembangan $\&$ penelitian (X2) berpengaruh positif terhadap variabel inovasi produk (Y2), maka hipotesis 3 dapat diterima.

Variabel manajemen pemasok (X4) memiliki nilai signifikansi t sebesar $0.008 \leq 0.050$, maka variabel manajemen pemasok (X4) berpengaruh positif terhadap variabel inovasi produk (Y2), maka hipotesis 6 dapat diterima.

Tabel 4.2 Hasil Analisis Regresi Berganda Tahap II

\begin{tabular}{lcccc}
\hline Variabel & $\begin{array}{c}\text { Koefisien } \\
\text { regresi }\end{array}$ & $\begin{array}{c}\text { t } \\
\text { hitung }\end{array}$ & Sig.t & Sig. 5\% \\
\hline Konstanta &,- 242 & & & \\
\hline $\begin{array}{l}\text { Fokus } \\
\text { Pelanggan }\end{array}$ &, 353 & 2,816 &, 009 & Signifikan \\
\hline $\begin{array}{l}\text { Pengembang } \\
\text { an \& } \\
\text { penelitian } \\
\text { Manajemen }\end{array}$ &, 321 & 2,331 &, 027 & Signifikan \\
\hline $\begin{array}{l}\text { Manajemen } \\
\text { Pemasok }\end{array}$ &, 374 & 2,861 &, 008 & Signifikan \\
\hline Variabel dependen : Inovasi Produk & & \\
\hline Adjusted R Square = 0.637 & & & \\
\hline F hitung = 18.585 & & & \\
\hline Sig.F = 0.000 & & & \\
\hline
\end{tabular}

Sumber: Data primer yang diolah, 2019.

Pengaruh fokus pelanggan, manajemen pengembangan \& penelitian, manajemen proses, dan manajemen pemasok secara bersama-sama terhadap kualitas produk dan inovasi produk pada UKM Mebel di Desa Tirtonirmolo, Kecamatan Kasihan, Kabupaten Bantul, DIY.

Hasil penelitian menunjukan variabel fokus pelanggan, manajemen pengembangan \& penelitian, manajemen proses, dan manajemen pemasok secara bersama-sama berpengaruh signifikan terhadap kualitas produk dan inovasi produk pada UKM Mebel di Desa Tirtonirmolo, Kecamatan Kasihan, Kabupaten Bantul, DIY. Hal tersebut menunjukan variabel fokus pelanggan, manajemen pengembangan $\&$ penelitian, manajemen proses, dan manajemen pemasok dapat lebih meningkatkan kualitas produk dan inovasi produknya menjadi lebih baik lagi sehingga dapat diterapkan secara bersama-sama pada UKM Mebel di Desa Tirtonirmolo, Kecamatan Kasihan, Kabupaten Bantul, DIY.

Pengaruh fokus pelanggan terhadap kualitas produk dan inovasi produk pada UKM Mebel di Desa Tirtonirmolo, Kecamatan Kasihan, Kabupaten Bantul, DIY.

Hasil analisis berganda diatas menyatakan bahwa fokus pelanggan berpengaruh signifikan terhadap kualitas produk dan inovasi produk. Hal ini dapat diartikan apabila fokus pelanggan meningkat maka kualitas produk dan inovasi produk pada UKM Mebel di Desa Tirtonirmolo, Kecamatan Kasihan, Kabupaten Bantul, DIY akan meningkat. Didalam Usaha Kecil Menengah (UKM), mencari kebutuhan pelanggan dan harapan pelanggan kemudian menyebarluaskan kebutuhan pelanggan ke perusahaan, lalu menjaga hubungan baik dengan pelanggan, dan menanggapi keluhan-keluhan pelanggan, serta mengukur kepuasan pelanggan dan mampu meningkatkan kualitas pelanggan. Hasil penelitian ini didukung oleh penelitian terdahulu yang dilakukan oleh Prajogo et al (2008) yang menyatakan bahwa variabel fokus pelanggan berpengaruh positif terhadap kualitas produk, namun tidak berpengaruh positif terhadap inovasi produk. Penelitian ini didukung juga oleh Mansour Zarra-Nezhad, Belghis Bavarsad, Behrouz Mousazadeh (2013) yang menyatakan bahwa variabel fokus pelanggan berpengaruh positif terhadap kualitas produk dan inovasi produk.

Pengaruh manajemen pengembangan \& penelitian terhadap inovasi produk pada UKM Mebel di Desa Tirtonirmolo, Kecamatan Kasihan, Kabupaten Bantul, DIY.

Hasil analisis regresi berganda diatas menyatakan bahwa manajemen pengembangan \& penelitian berpengaruh signifikan terhadap inovasi produk. Hal ini dapat diartikan apabila manajemen pengembangan \& penelitian meningkat maka inovasi produk pada UKM Mebel di Desa Tirtonirmolo, Kecamatan Kasihan, Kabupaten Bantul, DIY akan meningkat. Berkomunikasi dengan departemen lain, mengejar penelitian terdepan, melakukan proyek yang beresiko tinggi dengan tingkat pengembalian yang 
tinggi, pengembangan dan penelitian menjadi bagian dari strategi bisnis mampu meningkatkan inovasi produk. Hasil penelitian ini didukung oleh Prajogo et al (2008) yang menyatakan bahwa variabel manajemen pengembangan \& penelitian berpengaruh positif terhadap inovasi produk. Penelelitian ini didukung juga oleh Mansour Zarra-Nezhad, Belghis Bavarsad, Behrouz Mousazadeh (2013) yang menyatakan bahwa variabel manajemen pengembangan \& penelitian berpengaruh positif terhadap inovasi produk.

Pengaruh manajemen proses terhadap kualitas produk pada UKM Mebel di Desa Tirtonirmolo, Kecamatan Kasihan, Kabupaten Bantul, DIY.

Hasil analisis regresi berganda diatas menyatakan bahwa manajemen proses berpengaruh signifikan terhadap kualitas produk. Hal ini dapat diartikan apabila manajemen proses meningkat maka kualitas produk pada UKM Mebel di Desa Tirtonirmolo, Kecamatan Kasihan, Kabupaten Bantul, DIY akan meningkat. Menerapkan pelanggan internal, mendesain langsung produk yang preventif, intruksi yang terdokumentasi, menggunaka teknik statistik seperti SPC (Statistical Process Control/Chart) mampu meningkatkan kualitas produk. Hasil penelitian ini didukung oleh Prajogo et al (2008) yang menyatakan bahwa variabel manajemen proses berpengaruh positif terhadap kualitas produk. Penelelitian ini didukung juga oleh Mansour ZarraNezhad, Belghis Bavarsad, Behrouz Mousazadeh (2013) yang menyatakan bahwa variabel manajemen proses berpengaruh positif terhadap kualitas produk.

Pengaruh manajemen pemasok terhadap kualitas produk dan inovasi produk pada UKM Mebel di Desa Tirtonirmolo, Kecamatan Kasihan, Kabupaten Bantul, DIY.

Hasil analisis regresi berganda diatas menyatakan bahwa manajemen pemasok berpengaruh signifikan terhadap kualitas produk dan inovasi produk. Hal ini dapat diartikan apabila manajemen pemasok meningkat maka kualitas dan inovasi produk pada UKM Mebel di Desa Tirtonirmolo, Kecamatan Kasihan, Kabupaten Bantul, DIY akan meningkat. Menjalin hubungan jangka panjang dengan pemasok, menyeleksi pemasok agar mendapatkan bahan baku yang berkualitas, mengandalkan sebagian pemasok kecil yang handal untuk menjaga kualitas produk dan inovasi produk. Hasil penelitian ini didukung oleh Prajogo et al (2008) yang menyatakan bahwa variabel manajemen pemasok berpengaruh positif terhadap kualitas dan inovasi produk. Penelelitian ini didukung juga oleh Mansour Zarra-Nezhad, Belghis Bavarsad,
Behrouz Mousazadeh (2013) yang menyatakan bahwa variabel manajemen pemasok berpengaruh positif terhadap kualitas dan inovasi produk.

\section{KESIMPULAN DAN SARAN}

Berdasarkan analisis data tentang pengaruh aktivitas rantai nilai terhadap kualitas produk dan inovasi produk pada UKM Mebel di di Desa Tirtonirmolo, Kecamatan Kasihan, Kabupaten Bantul, DIY maka dapat diperoleh kesimpulan sebagai berikut: Fokus pelanggan berpengaruh positif signifikan terhadap kualitas produk pada UKM Mebel di di Desa Tirtonirmolo, Kecamatan Kasihan, Kabupaten Bantul, DIY. Manajemen proses berpengaruh positif signifikan terhadap kualitas produk pada UKM Mebel di di Desa Tirtonirmolo, Kecamatan Kasihan, Kabupaten Bantul, DIY. Manajemen pemasok berpengaruh positif signifikan terhadap kualitas produk pada UKM Mebel di di Desa Tirtonirmolo, Kecamatan Kasihan, Kabupaten Bantul, DIY. Fokus pelanggan berpengaruh positif signifikan terhadap inovasi produk pada UKM Mebel di di Desa Tirtonirmolo, Kecamatan Kasihan, Kabupaten Bantul, DIY. Manajemen pengembangan \& penelitian berpengaruh positif signifikan terhadap inovasi produk pada UKM Mebel di di Desa Tirtonirmolo, Kecamatan Kasihan, Kabupaten Bantul, DIY. Manajemen pemasok berpengaruh positif signifikan terhadap inovasi produk pada UKM Mebel di di Desa Tirtonirmolo, Kecamatan Kasihan, Kabupaten Bantul, DIY.

\section{REFERENSI}

[1] Amit dan Schoemaker, Strategic assets and organizational rent, Strategic Management Journal, 1993, 14(1): 33-46

[2] Barney J.B, Firm resource and sustained competitive advantage, Journal of Management, 1991, 17(1): 99-120

[3] Cho H.J dan Pucik V, Relationship between innovativeness, quality, growth, profitabillity, and market value, Strategic Management Journal, 2005, 4(3): 555-75

[4] Collis, D.J dan Montgomery C.A, 1997, Corporate strategy: Resources and the scope of the firm: Irwin Chicago

[5] Daulay Sere S, Regulasi bagi industri berbasis kayu dan hasil hutan, Widyaiswara Madya Pusdiklat Industri, 2015

[6] De Jong, J.P.J dan Vermuelen P.A.M, Determinant of product innovation in small 
firms: a comparison a cross industries, International Small Business Journal, 2006, 24(6): 587-609

[7] Deming W.E, 1986, Out of the Crisis, MIT Press, Cambridge, MA

[8] Dwyer, R.F, Schurr, P.H and Oh, S, Developing Buyer-Seller Relationship, Journal of Marketing, 1987, 51: 11-27

[9] Feller A, D Shunk and T Callarman, Value Chains Versus Supply Chains, BP Trends, 2006: $1-7$

[10] Fynes B, De Bu'rca S dan Voss C, Supply chain relationship quality, the competitive environment and performance, International Journal of Production Research, 2005, 43(16): 3303-20

[11] Ghozali, Imam, 2009, Aplikasi Analisis Multivariate dengan Program SPSS, Semarang: UNDIP

[12] Grant R.M, 2002, Contemporary Strategy Analysis: Concepts, Techniques, Applications, Blackwell: Malden, MA

[13] Goffin K dan New C, Customer support and new product devolepment-an exploratory study, International Journal of Operations \& Production Management, 2001, 21(7): 275-301

[14] Griffin, W, Ricky dan Ronald J Ebert, 2002, Management, Jakarta: Erlangga

[15] Hackman J.R dan Wageman R, Total quality management: empirical, conceptual, and practical issues, Administrative Science Quartely, 1995, 40(2): 203-70

[16] Hall L.A dan Bagchi-Sen S, A study of R\&D, innovation, and business perfomance in the canadian biotechnology industry, Technovation, 2002, 22(4): 231-44

[17] Harryson S.J, How canon and sony drive product innovation through networking and application-focused R\&D, Journal of Product Innnovation Management, 1997, 14(4): 288-95

[18] Helfat, Guest editor's introduction to the special issue: the evolution of firm capabilities', Strategic Management Journal, 2000(21): 95560

[19] Helfat C.E dan Peteraf M.A, The Dynamic Resource-Based View: Capability Lifecycles. Strategic Management Journal, 2003, 997-1010

[20] Hitt M.A, Ireland R.D, dan Hoskisson R.E, 2001, Manajemen Strategis: Daya Saing dan Globalisasi Konsep Buku 1, Jakarta: Salemba Empat
[21] Irmawati, 2007, Pengaruh Manajemen Rantai Pasokan Terhadap Terhadap Kinerja di PTPN VII Gunung Mas Bogor, Skripsi pada Departemen Manajemen, Fakultas Ekonomi Manajemen, Bogor: IPB

[22] Juran J.M, 1989, Juran Leadership for Quality: An Executive Handbook, Free Press, New York, NY

[23] Kotler P dan Keller KL, 2012, Manajemen Pemasaran Jilid 1 Edisi ke 12, Jakarta: Erlangga

[24] Lowe P, 1995, The Management of TechnologyPerception and Opportunities, Chapman \& Hall, London

[25] McGinnis S.M dan Vallopra R.M, Purchasing and supplier involvement: issues and insights regarding new products success, Journal of Supply Chain Management, 1999, 35(3): 4-15

[26] Mikkola J.H, Portfolio management of R\&D projects: implication for innovation management, Technovation, 2001, 21(7): 42335

[27] Montgomery, 1997, Corporate strategy: Resources and the scope of the firm, Irwin: McGraw Hill

[28] ------ dan Hariharan, Diversified Expansion by Large Established Firms, Journal of Economic Behavior, 1991(4): 71-89

[29] ------ dan Wernerfelt, Diversification, ricardian rents and tobin's q, Rand Journal of Economics, 1988, 623-632

[30] Munizu, Pengaruh Faktor-Faktor dan Internal Terhadap Kinerja Usaha Mikro dan Kecil (UMK) di Sulawesi Selatan, Jurnal Manajemen dan Kewirausahaan, 2010, 12(1): 33-41

[31] Noori S dan Ebrahimi M, Knowledge management tool for product innovation management, modiryad farad, Journal of Information, Education and Research, Tehran

[32] Peck H, Drivers of supply chain vulnerability: an integrated framework, International Journal of Physical Distribution \& Logistic Management, 2005, 14(3): 210-32

[33] Peteraf M.A, The cornerstones of competitive advantages: a resource-based view, Strategic Management Journal, 1993, 14(3): 179-92

[34] ------------- dan Barney J, Unraveling The Resource-Based Tangle, Managerial and Decision Economics, 2003, 309-323

[35] Porter M.E, 1994, Keunggulan bersaing, Menciptakan dan Mempertahankan Kinerja Unggul, Jakarta: Binarupa Aksara 
[36] Prajogo D.I, McDermott P, Goh M, Impact of value chain activities on quality and innovation, International Journal of Operations \& Production Management, 2008, 28(7): 615-635

[37] Sahay B.S dan Mohan R, Supply chain management practice in Indian industry, International Journal of Phsycal Distribution \& Logistic Management, 2003, 33(7): 582-606

[38] Santos-Vijande M.L dan Alvarez-Gonzalez L.I, TQM and firms performance: An EFQM excellence model research based survey, International Journal of Business Science Applied Management, 2007, 2(2)

[39] Shingo S, 1986, Zero Quality Control: Source Inspection and the Poka-yoke System, Productivity Press, Cambridge, MA

[40] Siringoringo H.R, Madya W, Manajemen proses inovasi, Pusdiklatwas BPKP. 2012

[41] Som O, Innovation without R\&D, Heterogeneous Innovation Patterns of NonR\&D-Performing Firms in the German Manufacturing Industry. Gabler Verlag, 2012

[42] Suendro G, Analisis Pengaruh Inovasi Produk Melalui Kinerja Pemasaran Untuk Mencapaian Keunggulan Bersaing Berkelanjutan (Studi Kasus Pada Industri Kecil dan Menengah Batik Pekalongan), Jurnal Fakultas Magister Manajemen UNDIP Semarang, 2010, 1-24

[43] Sugiyono, 2011, metode Penelitian Pendidikan Pendidikan Pendekatan Kuantitatif, Kualitatif, dan $R \& D$. Bandung: Alfabeta

[44] Sumarsono, Sonny, 2004, Metode Riset Sumber Daya Manusia, Yogyakarta: Graha Ilmu
[45] Sutoyo, Anwar, 2009. Pemahaman Individu, Observasi, Checklist, Interview, Kuesioner dan Sosiometri, Yogyakarta: Pustaka Pelajar

[46] Teece D.J, Pissano, G and Shuen, A, Dynamic capabillities and strategic management, Strategic Management Journal, 1997, 18(7): 509-33

[47] Terry G, 2005, Dasar-Dasar Manajemen, Jakarta: PT, Bumi Aksara

[48] The International Organization for Standarization, 2000

[49] Tjiptono, 2003, Strategi Pemasaran, Edisi 3, Yogyakarta: Andi Offset

[50] Tjiptono, 2008, Strategi Pemasaran, Edisi 3, Yogyakarta: Andi Offset

[51] Uma Sekaran, 2006, Metodologi Penelitian untuk Bisnis, Edisi 4, Jakarta: Salemba Empat

[52] Wernefelt, B, A resource-based view of the firm, Strategic Management Journal, 1984, 5(2): 17180

[53] Winter S.G, The economic of strategic opportunity, Strategic Management Jounral, 2003, 24, 977-990

[54] Zarra-Nezhad M, Bavarsad B, Mousazadeh B, Impact of value chain activities on product quality and innovation: The case study of Khuzestan industries, European Journal of Scientific Research, 2013, 108(3): 368-378

[55] www.kemenperin.go.id

[56] https://jogjaprov.go.id 